\title{
ENGLISH MNEMONIC LEXICON: CONSTITUENT STRUCTURE AND VERBALIZATION POTENTIAL
}

\author{
Irina Tivyaeva \\ Moscow City University, Russia \\ Olga Syomina \\ Tula State University, Russia
}

\begin{abstract}
This paper presents a study of the system of lexical devices used by English speakers to verbalize their personal memory experiences. The approach presented in the paper presupposes inclusion of nonnarrative structures into the spectrum of language forms conveying mnemonic meanings and extends the latter so as to encompass the meanings of encoding, storage, retrieval and loss. The research is based on the hypothesis that lexical units expressing memory-related meanings in English constitute a specifically organized system. A variety of communicative contexts representing mnemonic situations are analyzed as to develop a typology of memory verbalizers in English, estimate their functional potential and role in objectifying personal memory experiences on the lexical level. The results confirm the original hypothesis and suggest that mnemonic lexicon as a linguistic reflection of the mnemonic faculty is an important and largely understudied element of the language - memory system.
\end{abstract}

Keywords: memory, mnemonic process, mnemonic lexicon, memory verbs, communicative context

\section{Article history:}

Received: 31 March 2020;

Reviewed: 5 April 2020;

Revised: 23 April 2020;

Accepted: 1 May 2020;

Published: 30 June 2020

\author{
Contributor roles: \\ Conceptualization: I.T. (lead); Investigation: I.T., O.S. (equal); \\ Methodology: I.T., O.S. (equal); Data curation: I.T. (lead); \\ Formal Analysis: I.T. (lead), \\ Writing original draft: I.T. (lead); \\ Writing - review and editing: O.S. (lead);
}

Copyright (C) 2020 Irina Tivyaeva and Olga Syomina

cC (7) (8) This open access article is published and distributed under a CC BY-NC 4.0 International

License which permits non-commercial use, distribution, and reproduction in any medium, provided the original author and source are credited. Permissions beyond the scope of this license may be available at tivyaeva@yandex.ru. If you want to use the work commercially, you must first get the author's permission.

Citation: Tivyaeva, I., \& Syomina, O. (2020). English Mnemonic Lexicon: Constituent Structure and Verbalization Potential. English Studies at NBU, 6(1), 29-68. https:// doi.org/ 10.33919/ esnbu.20.1.2

Irina Tivyaeva, Dr. phil. habil., is Full Professor with the Department of Linguistics and Translation Studies, Institute of Foreign Languages, Moscow City University, Russia. She teaches courses in linguistics, stylistics, intercultural communication, translation studies, and English as a foreign language. Her research interests include linguistic memory studies, cognitive linguistics, psycholinguistics, communication theory, translation studies, English for academic purposes. Irina Tivyaeva has published a monograph on linguistic coding of memory processes which has received several rewards from different foundations for academic excellence and innovation.

E-mail: tivyaeva@yandex.ru

https:// orcid.org/ 0000-0002-6316-784X

Olga Syomina, $\mathrm{PhD}$, is Associate Professor with the Department of Linguistic and Translation Studies, Institute of Social Sciences and Humanities, Tula State University, Russia. Her teaching and research interests lie in the field of lexicology, lexicography and corpus linguistics, particularly, applied English lexicology and comparative English-Russian corpus studies. She has published a number of research articles on English word stock and lexical problems of translation.

https:// orcid.org/ 0000-0001-7608-9118 
Memory has traditionally been one of the central concepts in philosophy and psychology, but recent decades have seen its persistent penetration into other research fields (see Assmann, 2008; Erll, 2011; Halbwachs, 1997; Hirsch, 2008; Klein, 2000), linguistics being no exception (see Bragina, 2007; Chafe, 1973; Gasparov, 2010; Smorti, Peterson \& Tani, 2016; Wierzbicka, 2007). Theories and models describing memory language relationships vary significantly across fields and authors. Nevertheless, whatever stands are taken by scholars in regard to the particular role posited for language in relation to memory and whatever arguments are proposed in the continuing debate about the extent of linkages between memory and language, there is a general understanding among researchers that language is a tool allowing for conscious access to and sharing of mnemonic content, and much of memory-related communication is accomplished through language channels (Howe \& Courage, 1997; Fivush, 1999; Fivush \& Nelson, 2004). Therefore, as it is generally accepted that memory finds its reflection in the language, it is logical to turn to verbal reports to explore how exactly memory is represented linguistically, whether there are any correlations between mnemonic content, mnemonic processes and language means used to express them.

\section{Theoretical background}

Previous findings clearly highlight two tendencies prevailing in the linguistic field of memory studies: the tendency to equate memory with the final stage of cognitive processing, that is, with the operation of retrieval, and the tendency to overlook verbal "products" of memory other than narrative. Recent studies have examined memory-related use of language in connection with reporting past events (Amberber, 2007; Tivyaeva, 2014; Tivyaeva, 2017) while mnemonic activities are not limited to archival memory and reconstructing the past. Human memory also embraces present and future when encoding information, keeping it up to date and ready to use whenever required and making plans and ensuring their realization. The longstanding concept of memory as an archive of the past is currently undergoing a profound transformation as our understanding of memory is being enriched with new perspectives offered by the cognitive science, humanities and social studies (Brockmeier, 2015). However, systematic linguistic data pertaining to ways of transmitting the mnemonic meaning in all of its totality and complexity are still lacking. 
Therefore, drawing on the contemporary psychological view of individual memory as a cognitive system of information processing, in the current study the authors aim to explore how remembering, storing, recalling and forgetting are manifested linguistically, specifically, on the lexical level.

In the present study, we focus primarily on individual memory and ways it is lexicalized in English mostly due to the fact that it has been unambiguously described in terms of structural elements, that is, cognitive processes that may be represented by verbal means. As for collective memory, despite the fact that researchers accentuate profound importance of language for collective memorial practices (Assmann, 1995; Halbwachs, 1992; Ricoeur, 2004;) and, when conceptualizing the term 'collective memory', tend to describe it as deeply related to linguistic and narrative phenomena (Hirst \& Echterhoff, 2012; Mlynář, 2014; Wertsch, 2008), there is no universal understanding of the nature of its relation to language. The vagueness of the term and lack of research into linguistic dimensions of collective memory make it difficult to determine what language structures could be seen as its verbalizers, therefore, in this paper, our empirical data and findings are limited to individual memory.

As for language structures representing personal mnemonic experience, the standard verbal form conventionally used as a research unit in memory studies is narrative. With the narrative turn in the humanities and social sciences, the view of narrative as a linguistic reflection of memory has gained significant support among scholars dogmatically conferring narrative the status of the verbal counterpart of memory. Thus, R. Schank and R. Abelson similize memory to a corpus of narratives:

Human memory is a collection of thousands of stories we remember through experience, stories we remember by having heard them, and stories we remember by having composed them (Schank \& Abelson 1995).

J. Bruner argues that experience and memory of human happenings are organized mostly in the form of narratives that function as linguistic "versions of reality" (Bruner, 1991, p. 4). Howe and Courage accentuate the verbalizer function of narrative by labelling the latter "the language of autobiographical memory" (1997, p. 320). J. Brockmeier calls narrative the most adequate and possibly the only form in which the time of the autobiographical process can exist (Brockmeier, 2000). 
The primary focus of linguistic memory studies on memory-related narrative forms and discourse practices (Bellinger, 2010; Bondareva, 2014; Burima, 2010; Labov \& Waletzky, 1966; Nyubina, 2008, 2013; Paganoni, 2011; Rebrina, 2014) is a reflection of a more general trend observed in psychology and the humanities consisting in a growing interest for cultural and social phenomena characteristic of large collectives rather than cognitive and personal spheres incident to individuals. For instance, Potter and Wetherell acknowledge the disconnection between cognitive science and discourse analysis stressing the independence of the latter from cognitive representations:

Discourse analysis has eschewed any form of cognitive reductionism, any explanation that treats linguistic behavior as a product of mental entities or processes, whether it is based around social representations or some other cognitive furniture such as attitudes, beliefs, goals or wants. The concern is firmly with language use: the way accounts are constructed and different functions. (Potter \& Wetherell, 1987, p. 157)

Consequently, not much linguistic memory research has overstepped the borders of narrative and discourse analysis to look into other spectra of language devices transmitting various mnemonic meanings. However, over the last few years a new literature has been emerging that allows for transmission of mnemonic meanings by language structures other than narratives (Brockmeier, 2018; Haden \& Wilkerson, 2010; Hedrick et al., 2009; Schwartz, 2013). In this paper our argument is that the conventional narrative approach to memory verbalization cannot accommodate all possible ways of linguistic encoding of mnemonic content because within its framework the natural structural variety of personal memory reports gets reduced to the stereotype narrative form; at the same time, content and structural analysis of a broad range of communicative contexts reflecting mnemonic experiences could open up possibilities for studying linguistic representation of individual memory in multiple ways, taking into account both its processual complexities and communicative dimensions.

In this paper, we seek to bridge the gap by extending the memory-language interrelation studies into the linguistic domain per se and making more profound inquiries into the verbal representation mechanism, specifically, its lexical level, which 
would be important to gain an in-depth understanding of how cognitive phenomena get reflected in language.

As the perspective in the study of meaning shifted from structuralist views to the idea of frame as a cognitive structure (see Filmore, 1975; Langacker, 1991), the study of lexicalization patterns has been increasingly based on the idea of one-to-many correlation between semantic elements and surface elements and the ensuing assumption that languages differ systematically in the way conceptual components are verbalized in distinct structures (Talmy, 1985). Much attention has been given to how "words evoke knowledge about the world, and thoughts about the world are conveyed through words" (Malt et al., 2010, p. 29). In other words, to the general regularities of how a cognitive structure correlates to its lexical representation (see Bierwisch and Schreuder, 1992; Filipović, 2007; Lehmann, 1990; Lakoff \& Johnson, 1980; Malt et al., 2010; Slobin, 2004), as well as to typological studies of differences and similarities between lexicalization patterns in certain languages in various spheres, such as motion (see the extensive literature review in Levin and Rappaport Hovav, 2019), parts of body (Majid et al., 2006), colour (Raffaelli et al., 2019), mental states (Goddard, 2010), and threat (Gaus \& Riabova, 2019).

The present study is intended to be a small step in this direction, investigating the lexical component of the verbal code used to represent memory content in English. Therefore, the purpose of the current paper is threefold: (1) to extend the exploration of the relation between memory and linguistic categories to language devices and structures other than narrative; (2) to expand research on verbal representation of individual memory in order to encompass linguistic devices used to manifest memory operations; (3) to determine lexicalization patterns representing the mnemonic faculty in English.

Certain issues of memory objectification on the lexical level have already been discussed in past literature (see Golajdenko, 2012; Iskhakova \& Khomyakova, 2009; Morimoto, 2016; Rebrina, 2008; Skoromyslova, 2003; Uehara, 2015). Linguists have addressed the use of memory verbs and collocations in different languages and discourse varieties (Rebrina, 2015; Zaliznjak, 2006), reflection of cultural memory in lexemes and idioms (Wierzbicka, 2001; Maslova, 2001; Skorobogatova, 2013), metaphoric representation of memory (Barančeeva, 2014). However, the obtained 
results, despite their obvious value as regards specific languages and cultures, did not allow treating memory verbalizers as an organized system, on the one hand, and did not demarcate conclusions valid for individual memory and different forms of collective memory, on the other. In this paper, we attempt to address this void and provide a thorough analysis of the English lexicon of personal memory with a special emphasis on its systemic organization.

The present-day understanding of individual memory as a system of mnemonic processes (Sereda, 1985; Ogorodnikova, 2012) determined the scope of lexis to be included into the study. In accordance with information processing theories (Atkinson \& Shiffrin, 1968; Baddeley, 1986; Craik \& Lockhart, 1972; Loftus \& Loftus, 1975), cognitive processing in memory presupposes four stages (encoding, storage, retrieval, and loss), therefore, our interest lies with language units lexicalizing the said mnemonic operations in English. The stock of lexical items conveying the meanings of encoding, storing, recalling, and forgetting will be further referred to as the mnemonic lexicon.

Accepting in general the view of organized lexical representation of memory with English memory verbs proposed by Rogačeva (2003), in the present paper we seek to validate it with more extended evidence not limited to example sentences reflecting the current usage of pre-defined mnemonic lexicon and further promote the idea of nonrandom choice of linguistic devices when verbalizing mnemonic experiences. We hypothesize that memory representation in natural languages (specifically in English which is used as a source of empirical data in this research) relies on regular lexicalization patterns. Our supposition is based on three arguments: 1) the concept of organized lexicalization applied to studying mnemonic verbs in Rogačeva (2003), 2) the idea of language and communication patterns widely accepted in mainstream linguistics and communication studies, 3) observation of language data strongly suggesting that the spectrum of lexical devices encoding memory operations transgresses the boundaries set by past research.

Preliminary observations of language data selected from various publicly available sources allow formulating the hypothesis as follows: English mnemonic lexicon has a complex system-based structure that includes two major groups of lexical items: 1) memory-related lexemes and collocations nominating mnemonic processes directly, 2) lexical items semantically unrelated to memory but capable of representing 
mnemonic operations in context. The choice of lexical means for verbal encoding of memory content is determined by cognitive factors (the mnemonic process being verbalized) and communicative context (broad communicative conditions under which mnemonic content is transmitted).

\section{Data and Methods}

To confirm or disconfirm the hypothesis, a relevant research procedure was developed and empirical data was manually collected. As previous studies have focused mostly on analyzing specific lexemes (memory verbs) or text types (narratives), the yielded results were subject to language data under analysis. In the current research our choice was naturally occurring texts, specifically, text fragments illustrating verbal communication in cognitive situations of encoding, storing, retrieval and loss of information, as opposed to data collected in the course of interviews and often following pre-determined lexical and structural patterns set by the researcher's questions. All of the language samples used in this study are authentic material retrieved from British and American open sources in strict accordance with the cognitive and communicative criteria of relevance and disengagement, that is, a language sample was registered in the corpus if it represented a verbal accompaniment of a memory operation and was a product of natural communication, not subject to experimental conditions or a scholarly design.

Thus, the empirical basis of the paper is a language corpus containing 7,500 communicative contexts which were selected from publicly available open sources (both online and print) representing different discourse varieties. The items included into the corpus are thematically coherent and reflect verbal actions undertaken by speakers in memory-related situations.

Structurally language samples registered in the corpus can be classified into three types: memory conversations, memory monologues, and memory narratives. Drawing on empirical evidence, we propose broader definitions of memory conversations and memory monologues than found in Schwartz (2013) and Cohn (1983) respectively. Memory conversations are understood as verbal exchanges between speakers concerning mnemonic content (retrospectively or prospectively oriented). Memory monologues mostly deal with past happenings reconstructed from the agent's memory but can also represent mnemonic experiences related to the future. 
Memory narratives are contrasted to memory monologues as language structures characterized by a specific internal organization that follows reconstructed events and subjects in their development.

The goals of the present paper dictate that a complex of research methods and procedures be used to provide balanced and reliable results. Theoretical methods comprise providing a critical review of earlier findings concerning linguistic devices used to objectify mnemonic operations and developing solid theoretical foundations for the proposed hypothesis. Empirical methods embrace the continuous sampling method and content analysis selected for collecting relevant language data from open sources; cognitive interpretation that allows determining the stage of cognitive processing of the mnemonic content being verbalized in each of the language samples; lexicographic analysis used to define and specify meanings of lexical items under consideration; the linguistic observation method, text analysis, contextual and discourse analysis applied to single out linguistic ways of manifesting mnemonic experiences and identify regular lexicalization patterns.

\section{Results and Discussion}

As dictated by the goals of the study outlined in the previous section, a relevant research procedure was developed. The present inquiry was conducted in three stages. In the first step of the investigation our focus was on lexical features of language samples, specifically, memory-related lexemes and lexical units acquiring memoryrelated meanings under contextual conditions. Content and lexicographic analysis of the language material allowed identifying the component structure of the English mnemonic lexicon and singling out its semantic and structural features relevant to the study. The second stage of the research was designed to estimate the potential of differentiated constituents of the mnemonic lexicon in relation to transmitting mnemonic meanings. Finally, in the third phase of the inquiry lexicalization patterns were marked out and their salience was assessed empirically.

\section{Constituent structure of mnemonic lexicon}

First, we concentrated on lexical realizations of mnemonic meanings. Each of the items registered in the corpus was handled manually. No automatic linguistic analysis software was used as the task in this stage was to detect all lexical devices (either 
semantically related to memory or not) that contribute to verbal representation of mnemonic operations. The data revealed four groups of lexical units expressing memory-related meanings either systematically or contextually: memory verbs, memory nominals, memory collocations, and non-mnemonic lexis used metonymically.

Memory verbs appeared to be the most recurrent group prevailing in the data under examination. Their position of the most frequently occurring lexical device representing mnemonic content provides an explanation for them being assigned the status of primary memory verbalizers. Results of the qualitative analysis yielded a list of English verbs for which memory-related meanings were systemic (for the complete list, see Table 1 below).

\section{Table 1}

Memory verbs and their potential regarding verbalization of mnemonic processes

\begin{tabular}{lcccc}
\hline \multirow{2}{*}{ Memory verb } & \multicolumn{5}{c}{ Memory processes } \\
\cline { 2 - 5 } & Encoding & Storage & Retrieval & Loss \\
\hline remember & + & + & + & + \\
recall & & & + & + \\
reminisce & & + & + & + \\
recollect & & + & & + \\
remind & + & + & & \\
forget & & & & \\
memorize & & + & & \\
misremember & & & & \\
unforget & & & & \\
mind & & & & \\
\end{tabular}

The obtained results are very much in line with Rogačeva's (2003) findings, yet there are a few discrepancies regarding the total number of items on the list. While the study conducted by Rogačeva (2003) reports nine verbs in English expressing memoryrelated meanings, the number of memory verbs occurring in our corpus was ten. The differences concern the verb to bethink which is included on the list by Rogačeva (2003) as showing semantic properties indicative of its systemic memory-related meaning while our material reveals zero occurrence for the verb.

Another difference between our results and Rogačeva's (2003) findings concerns two memory-related verbs - to misremember and to unforget - that appeared in several language samples but, to the best of our knowledge, until now have not been studied as 
lexical units capable of expressing mnemonic meanings. The number of occurrences in our corpus is under $1 \%$, however, despite the low occurrence rate, the cases could not be ignored as that would have corrupted the results. Examples (1) and (2) below illustrate the use of the verbs to misremember and to unforget respectively, expressing memory-related meanings.

(1) If you first state the false information and then provide evidence of why it is wrong, people will tend to forget over time the evidence for why it is wrong, and start to misremember the original falsehood as true. (Tsipursky, 2018)

(2) Thwack! comes the noise once more. It takes several minutes to remember to forget my random thoughts, and to unforget my breathing. (Leaf, 2002)

After the list of English memory verbs was finalized, we proceeded to scrutinizing their potential as regards representation of specific stages of mnemonic processing. As suggested by the language data, memory verbs differ in their abilities to communicate various mnemonic meanings, that is, while some verbs are semantically capable of manifesting two or more stages of mnemonic processing, others are restricted in their usage. The verb to remember demonstrated the highest potential regarding verbalization of memory as a lexeme expressing any mnemonic process. Its use as a lexical verbalizer of memory input, storing, retrieval and forgetting is illustrated by Examples (3), (4), (5) and (6) respectively.

(3) I will remember Tony Blair as the man who conclusively awakened my apathy towards party politics. (Busfield, 2007)

(4) I remember daydreams about being a concert pianist. I remember longing to have an older brother. My father was a widower when he married my mother. I used to fantasize that a half-brother would turn up out of the blue. (Cope, 2014)

(5) After all, when I think of myself at 14, watching the couple across the carriage aisle, I am not remembering them, I am remembering myself; innocent and yearning, but also a greedy voyeur rapping on the glass, wanting to be let in. (Abbott, 2014)

(6) "I can't see a scenario where I would say that. What I can see is, it was 10 years ago and I don't remember saying it. When someone says you said something, like the experience we just had right now - I don't remember saying that." (Bakare, 2018)

The verb to remember is followed by three other constituents of the same semantic group registered as lexical markers of two mnemonic processes. Thus, to recall and to recollect can both objectify retrieval and loss of information (see (7a, b) and (8a, b) 
respectively) while the semantics of to forget allows it to be used as a lexical verbalizer of storing information in memory and loss of information as illustrated in $(9 a, b)$.

(7a) As I recollect the view point's as a child, I remember going to one of the sites where my dad was rebuilding a burned down church. (Sweet, 2017)

(7b) I recall one day, about a month before she passed, I was driving home from the hospital and decided to stop at Nordstrom. (Russell, 2018)

(8a) "In fact, I have no memory of this alleged incident," he added. "Brett Kavanaugh and I were friends in high school, but I do not recall the party described in Ford's letter. More to the point, I never saw Brett act in the manner Dr. Ford describes." (Herreria Russo, 2018)

(8b) I cannot recollect the circumstances of my A-level results. (Ratcliffe, 2013)

(9a) I may never know their names, but I will never forget what they did for me and my family. (Piazza, 2019)

(9b) Sometimes, as Loudon Wainwright III put it, I forget. I forget why I'm paying E5 a month to Macmillan Cancer Support and have been doing so for 20-odd years. (Jeffries, 2014)

The verbs to reminisce, to remind and to memorize denote only one mnemonic process each, showing lower potential than the abovementioned constituents.

(10a) I reminisce on the numerous ways I could have compromised myself or sacrificed my worth, had it not been for that constant refrain running in the back of my mind "save some for later." (Lawn, 2017)

(10b) I was reminded of Austerlitz, that meditation on war by WG Sebald, in which "we who are still alive are unreal in the eyes of the dead, and only occasionally, in certain lights and atmospheric conditions, do we appear in their field of vision". (Adams, 2018)

(10c) About a week later, the panic began to set in over the fact that I had to learn and memorize an obscene amount of music in such a short period of time. It's just Christmas music, you say? No, no. I had to memorize nearly 100 tunes with complex harmonies and obscure lyrics, figuring out where my part melted into the others. I had to memorize my starting pitch based off the blown pitch and perfect my ear training to ensure I came in exactly on my note. (Gould, 2018)

Finally, the remaining three verbs on the list have limited potential regarding verbal representation of mnemonic experiences, being capable of expressing only one memory process developing under certain modalities as illustrated in (1) and (2). As a result, the said verbs are characterized by functional restrictions conditioned by their specific semantics. 
The overall results of the qualitative and quantitative evaluation of the language data presented in this section demonstrate that the total number of English memory verbs directly nominating mnemonic operations amounts to ten. The said lexical units form a semantic group in which each component expresses a memory-related meaning as its primary one. However, it should be noted that this semantic group is characterized by a heterogeneous structure as the majority of its constituent members convey mnemonic meanings not loaded with any additional submeanings while three peripheral low frequency constituents objectify mnemonic meanings loaded with modifiers specifying external consequences attending the processes.

Another significant group of lexical items transmitting mnemonic meanings and serving as regular lexical markers of personal memory includes verbal collocations used as functional equivalents of memory verbs. In this study we restricted our analysis to frequently occurring collocations with verbal heads that are semantically equivalent to memory verbs and function as contextual synonyms of verbs systematically expressing memory-related meanings (for example, "to have a flashback" (= to recall), "to stir up in memory" (= to remember), "to wipe from memory" (= to forget), etc.). Non-verbal memory collocations, non-recurrent memory-related verb phrases or memory-related collocations that do not objectify any mnemonic processes directly (see (11a-c) below) were not included into the analysis.

(11a) to test memory as in

I used to test my memory by recalling all the shops in the drenched Hollywood street (French, 2000)

(11b) to toy with memory skills as in

\section{I kept toying with my memory skills (Cooke, 2015)}

(11c) to deny recollection as in

The former Lehman Brothers boss Dick Fuld has denied all recollection of an accounting trick... (Clark, 2010)

The findings reveal that verb-equivalent memory collocations possess a stable internal structure based on a number of regular models and demonstrate consistent functional patterns. In accordance with the results, it is possible to differentiate four structural models providing bases for verbal collocations marking mnemonic processes in English. 
Model 1: Verb for a singular or plural noun with or without a determiner, systematically conveying a

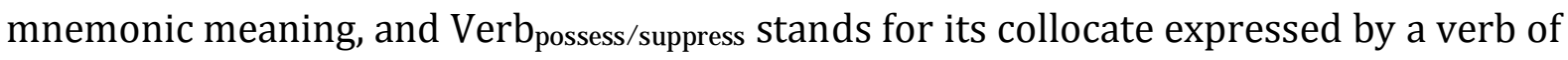
possession, suppression or causation of emergence as illustrated in the following example:

(12) It might be possible to trigger the memory if there was a life size simulator we could sit in and go through the event one more time. Or not. (Is it possible to remember being born?)

Model 2: Verb $b_{\text {possess/suppress }}$ - Mnemonic Noun + Preposition, in which Mnemonic Noun stands for a singular or plural noun systematically conveying a mnemonic

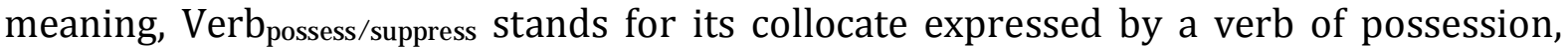
suppression or causation of emergence, and Preposition denotes a preposition pointing either at an object of the mnemonic process being verbalized or at a period of time associated with the process. Mnemonic Noun in this model can also be preceded by an article, a pronoun, or an adjective usually specifying circumstances under which the marked process takes place. The example below demonstrates realization of this model in speech:

(13) "I have a memory of turning around and [thinking], What was that? What am I supposed to do with it? What does it mean? The older I get, and the more I know, I feel very fortunate that something worse didn't happen." (Sieczkowski, 2017)

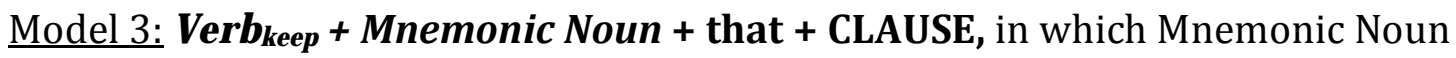
stands for a memory-related noun with a possible attribute in preposition, Verb $b_{\text {keep }}$ stands for its verbal collocate expressing possession, keeping, emergence, expression or suppression, and CLAUSE points at an objective or attributive clause providing a description of the mnemonic actant. For instance:

(14) I have a vague recollection that his name was actually 'Flash', although as it must have been twenty odd years since I last watched it, I might be wrong... (What was the name of the tortoise in the seventies kids programme "Pipkins"?)

\section{Model 4: Verb imprint/suppress $_{\text {+ Noun/Pronoun }}$ object $_{+}$Preposition + Mnemonic}

Noun, in which Verbimprint/suppress is the head element represented by verbs of imprinting

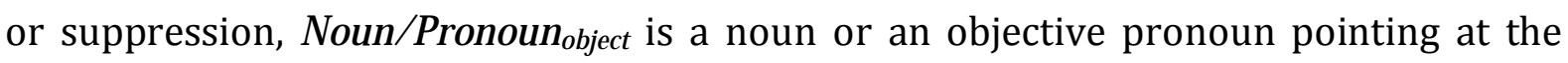
object of the memory process denoted by the verbal collocate, Preposition stands for a spatial preposition, and Mnemonic Noun stands for a memory-related noun possibly modified by an attribute or a determiner as in (15) below: 
(15) It had been years since she was outed as a CIA operative by Bob Novak resulting in her story catching fire in the press years ago, and quite frankly I had completely put her out of my memory. (Kazmir, 2017)

As indicated by empirical data, verb-equivalent memory collocations built on the basis of Models 1, 2 and 3 function as markers of three fundamental mnemonic processes: storing information in memory, retrieval and forgetting. The process of inputting information into memory is lexically signalled by verb-equivalent collocations structurally identical with Model 4.

According to the language data under analysis, English memory lexicon includes four groups of lexical verbalizers, two of which are composed of lexemes with systemic memory-related meanings, and the other two hold lexical items recurrently functioning as their contextual synonyms. The most frequent lexical devices marking mnemonic processes in communication were described above. Below we will present findings concerning the non-core lexical units that still merit close inspection as their specific semantics and figurative use highlight certain properties and peculiarities of memory processing relevant for understanding the linguistic mechanism of transmitting mnemonic meanings.

In addition to memory verbs and verb-equivalent collocations, numerous communicative contexts were registered in which mnemonic meanings were conveyed by lexemes systematically expressing memory-related meanings and belonging to parts of speech other than the verb. Specifically, this group of English mnemonic lexicon is composed of nouns and adjectives directly referring to memory operations and experiences. The subgroup of nouns includes the following items: memory, flashback, recollection, reminiscence, recall, remembrance, misremembrance.

The most frequent noun marking mnemonic processes in English communication is memory, its high frequency being a result of a complex semantic structure that includes several systematic meanings associated with memory and its processes. This semantic peculiarity of memory has two functional consequences. On the one hand, the broad meaning does not set any functional limits, thus, the noun in question is freely employed by subjects of communicative situations representing any mnemonic operation. On the other hand, as it lacks specifics, it is often used in contexts indicating 
some kind of mnemonic activity without actually referring to any specific situations. For instance, in the example below, the noun memory refers the reader to past experience not specifying its status as "something stored in memory" or "something reconstructed from memory". It is due to the use of the verb to remember in the first sentence reflecting the relevant stage of cognitive processing as "keeping information in memory" that one can define the meaning of the noun in question as "something stored in memory".

(16) It is absolutely possible to remember something that you can't explain remembering. My earliest childhood memory was when I was roughly 5 months old. This memory looks like a dream when I'm remembering it - but it has actually happened. (Is it possible to remember being born?)

According to the results of lexicographic analysis of the language samples, the other nouns constituting the group of memory nominals, unlike the noun memory, express only two memory-related meanings: 1) a memory as a result of mnemonic processing, and 2) an act of memory retrieval. Recollection, recall and remembrance have practically identical dictionary definitions and function as synonyms. The nouns reminiscence and flashback have a more complicated semantic structure which is characterized by the presence of an evaluative component. Along with objectifying memory processes, the said lexemes also express supplementary meanings, specifically, the agent's assessment of past experience as positive or negative.

As for the other nominals objectifying stages of cognitive processing in English, they have limited potential regarding representation of mnemonic operations, as shown by the empirical data. Only five memory-related adjectives were registered: memorable, forgettable, forgetful, unforgettable and reminiscent. Memorable and unforgettable have quite similar meanings and define an object as not subjected to the operation of forgetting. Forgettable, on the contrary, signals that mnemonic traces of a relevant object can be easily eliminated. The same process of memory loss is also marked by forgetful which qualifies the experiencer as tending to lose information stored in memory. Finally, the fifth constituent of this numerically insignificant group, the adjective reminiscent, has two meanings relevant to the purpose of this study: 1) tending to remind one of something; 2) absorbed in or suggesting absorption in memories (Reminiscent, n.d.). The structure of its lexical meaning reflects its potential as regards verbal representation of two mnemonic processes: storing information in memory and 
recall, which makes it unique among other group constituents capable of objectifying only one memory process.

Thus, the group of nominal lexical markers of mnemonic processes in English is constituted by nouns and adjectives systematically expressing memory-related meanings. According to the language data under consideration, it comprises seven nouns, none of which, however, can function as an independent memory marker, and five adjectives selectively representing three of the four core processes.

As demonstrated by our language data, there is a large number of lexemes devoid of any memory-related semantics, but still taking significant part in verbal objectifying of mnemonic processes due to acquiring memory-associated meanings under specific contextual conditions. Based on the empirical evidence within the involved lexis, the following thematic groups of lexemes can be differentiated:

1) thematic group of mental processes and states,

2) thematic group of sensual perception,

3) thematic group of translocation,

4) thematic group of past experience.

The thematic group of mental processes and states as presented in our language samples includes two subgroups associated with thinking: 1) verbs denoting mental acts and states, including verbs of thinking, understanding, and knowing (for example, to know, to think, to reflect); and 2) nouns naming the hypothetical "thinking organ" that controls mental processes (for example, brain, mind, head). Examples (17) and (18) below illustrate how lexemes belonging to the two subgroups under consideration take part in rendering mnemonic content.

(17) It's funny thinking back on all this. My memories of the time is that Antonia had as usual some rehearsal for us and the character I was playing in Safe was crazy and it seemed to me that the rehearsals we were doing that week didn't help. (Carlyle, 1999)

In the fragment above the mental verb to think back is employed as a lexical marker of memory retrieval. Although its semantics does not presuppose expressing any memory-related meanings, in the given context to think back develops a contextual meaning of remembering. This modification in the meaning becomes possible due to other lexical and grammatical devices explicitly or implicitly pointing at personal memory experience. On the lexical level, memory reporting is manifested by two 
lexemes: memories standing for recollections of past experience and time accentuating a temporal gap between the moment of speaking and the events being reconstructed, the former being an explicit marker and the latter functioning as an implicit one. Structurally, the present and the time evoked in the agent's memory are demarcated by the adverbial that week amplifying the effect produced by the lexical means.

Example (18) below presents a case of a noun referring to the so called "memory organ" in the function of a supplementary lexical marker of mnemonic processes.

(18) I have a vague memory of being carried out to my mother who was laying on a hospital bed. I must have been a baby because I was in the palms of their hands. I also have vivid memories from when I was 12 months old. The human mind is a very powerful tool. You can unlock anything if you try. (Is it possible to remember being born?, n.d.)

The example is an utterance produced by a memory agent and describing his experience of storing information in memory. The process of storing information is not nominated directly. Its primary lexical markers are two verb-equivalent collocations have a vague memory and have vivid memories. The mental noun mind denotes a metaphoric storage of memories and in this quality it does not name any processes but rather performs a supporting role referring to cognitive processing in general.

Other lexemes within the thematic group of mental processes registered in our database demonstrate identical behaviour: being integrated into the broader context, verbs objectify the process of memory retrieval while nouns render general mnemonic means, not specifying any operations.

The thematic group of sensual perception has a similar structure as that of mental processes. The group includes verbs of sensual perception (for example, to feel, to see, to look), and nouns describing abstract entities available to an individual as a result of sensual perception of the surrounding world (for example, image, picture). In Example 19 below the verb of visual perception to look back is employed as an additional marker of mnemonic reconstruction. This lexical unit cannot be regarded as a direct memory verbalizer since semantically it has no relation to the mnemonic function, but representing past events as experience that can be visualized, it stresses their vivacity and presence in the agent's memory. The adjective past and adverb now accentuate the gap between the current situation and the period retrieved from 
memory and thus contribute to the contextual conditions activating the meaning of restoring from memory.

(19) When I look back on my past adventures now, it's the real, unstaged photos and seemingly pointless selfies that make my heart sing anyway - not the curated, overedited, completely inauthentic shots. (Kucheran, 2019)

The thematic group of translocation is constituted by verbs expressing transposition in space, specifically, verbs describing voluntary or involuntary change of location by an object relative to a landmark or independent of some other fixed object. The most numerous group constituents are reverse movement verbs denoting actions that return to the initial reference point. For instance, in the following fragment the reverse movement verbs to take back and to flood back mark the process of restoring information on the lexical level. At that, memory retrieval is represented as an externally initiated process not subjected to the experiencer's control, progressing regardless of their attitude and without any triggering actions on their part.

(20) But for me, the most potent floral scent is the coconut aroma of gorse. It takes me straight back, almost half a century, to the cake shop below my grandparents' flat in Southsea, where the comforting smell of warm coconut wafted from trays of macaroons. Such is the evocative power of this aroma that these childhood memories flooded back in photographic detail as I sat under a bank of gorse this afternoon, during the pre-Easter heatwave that coaxed a spectacular display of gorse flowers into bloom. (Gates, 2003)

Unlike the thematic groups of mental processes and sensual perception, the translocation group may objectify a second mnemonic process. Specifically, relevant evidence was received for verbs expressing leaving, departing, and removing that often in combination with prepositions away and off in postposition represent loss of information from memory. For instance, in the examples below the verbs to melt and to fade function as lexical markers of forgetting.

(21a) My memories of Sadie would melt away. My life would feel normal. (Kinsella, 2010)

(21b) After this, I have very few memories of Honza. He just seemed to fade away. (Litt, 2010)

Thus, the thematic group of translocation, being the only one constituted exclusively by verbs, contributes to lexical expression of two memory processes forgetting and remembering. Moreover, unlike in the other groups, the semantics of its 
constituents allows specifying the nature of memory processes as both voluntary and involuntary.

Finally, the fourth thematic group including constituents that can acquire memory-associated meanings represents past experience. Unlike the other three groups, it does not include any verbs. Its constituents are nouns and adjectives expressing retrospective semantics that can be further classified into lexemes explicitly pointing at a temporal distance (for instance, nouns past, retrospect, adjectives old, early, last, etc.) and lexemes denoting time periods and intervals (for example, lifetime, year, youth).

Similar to the thematic group of translocation, lexical units expressing retrospective semantics point at two memory processes - remembering and forgetting. For instance, in (22) below lexemes in bold with temporal or, more specifically, pastassociated meanings function as additional markers, thus signalling transition into mnemonic narration mode, supporting the single memory verb to remember and extending its meaning onto the whole passage, not just the proposition that follows.

(22) I know there was a time when things were all right. I went climbing in the hills out back, slid down on paper bags over the gold-colored grass, played in the creek, climbed the cherry tree. I do not remember a childhood of chaos. Only in retrospect would I term it chaotic. [...] It was a world that I, through the keyhole of years, watched and reached a small hand out and tried to touch. (Hornbacher, 1999)

As indicated by the language data, the layer of non-mnemonic lexis, although semantically not designed to express memory meanings, functionally plays an important role in verbalizing memory reports, its constituents performing both as objectifiers and amplifiers of mnemonic processes. Such transitions of meanings seem to be possible due to two factors: the broad semantics of the lexemes under consideration allowing for further contextual modifications, on the one hand, and linguistic conceptualization of memory as a mental organ as well as its strong interconnections with time and place.

Summing up the results obtained in the first stage of the research, it can be concluded that the English language has an extensive multi-level arsenal of linguistic devices used for transmission of mnemonic content in communication. Organizationally, English memory lexicon can be presented as a nuclear structure with the core memory 
vocabulary forming its central part and supplementary lexical layers constituting the periphery. The nucleus is built around memory verbs serving as primary verbalizers of the mnemonic function in English and their collocation equivalents, both capable of expressing any of the cognitive processing stages. The proximal periphery is constituted by non-mnemonic lexis functioning either as contextual verbalizers or as supplementary signals. The far periphery is formed by nominal lexical units semantically associated with memory, but functionally deficient as regards direct nomination of its operations.

\section{Constituent potential as regards transmitting of mnemonic meanings}

The previous section of the paper dealt with the structural organization of English memory lexicon, presenting an inventory of lexical devices employed by English speakers to convey their mnemonic experiences. As demonstrated by the empirical evidence, the language system offers a choice of lexical means for expressing mnemonic operations. The second stage of the current study was aimed at determining the potential of each group of lexical markers and assessing their impact as regards verbal representation of memory reports.

Results obtained in the course of analyzing language samples indicated that the dominant memory verbalizers functioning on the lexical level are memory verbs, the verb to remember being the absolute leader in this group as a lexeme capable of nominating any stage of cognitive processing, which, on the one hand, accentuates its autonomous status and independence of any supplementary lexical devices, but, on the other hand, may result in ambiguity requiring relevant specifiers and amplifiers. Nevertheless, this group can be qualified as autonomous since its constituents are direct lexicalizers of mnemonic processes.

As for linguistic devices involved in lexicalization of memory indirectly, semantic analysis of verb-equivalent memory collocations revealed that just like memory verbs the former objectify mnemonic operations, thus functioning as contextual synonyms of the latter. However, unlike memory verbs, verb-equivalent memory collocations expand their meaning beyond nominating specific processes to providing extra information about their nature and flow specifics. For example, memory collocations denoting loss 
of information include supplementary meanings reflecting its fundamental property the motivated or unmotivated nature of forgetting. Verbal collocates of suppression and deletion accentuate the intentional nature of the process while verbal collocates of disappearance indicate that the agent does not have control over forgetting.

The semantic structure of verb-equivalent collocations may also manifest the same property in memory retrieval. Specifically, verb collocates of emergence emphasize the unmotivated nature of remembering while verb collocates expressing causation characterize the relevant process as self-triggered, resulting from intentional cognitive operations on the part of the agent. It should be noted in this regard that selfcontrollability as a relevant feature of a memory process is expressed only by collocations verbalizing memory retrieval and forgetting. The processes of recording information and storing it in memory as lexicalized in recurrent verb collocations are not marked for any special characteristics that would allow drawing any conclusions about the agent's will and control over memory operations.

Thus, memory collocations in English are capable of representing all of the key stages of cognitive processing verbalized by speakers and functioning autonomously. However, their potential related to marking memory processes on the lexical level is not as high as that of memory verbs, which can be explained by at least two reasons. The first one is the frequency factor indicating that memory verbs have a significant statistical advantage. And the other reason is related to the broader semantics of memory verbs, not modified by any processual specifics, which also adds to their functional predominance.

Yet a weaker verbalization potential has been found in non-mnemonic lexis used metonymically that cannot function as autonomous lexical markers of mnemonic content since their original semantics is not related to memory. Acquiring contextual memory-associated meanings under certain cognitive and communicative conditions, lexical constituents of the thematic groups of mental processes, sensual perception, translocation, and past experience take part in manifesting memory processes as supplementary markers playing a supporting role to words of mnemonic semantics and activating their systematic meanings. 
This lexical layer has a peculiar feature setting it off the other groups of words within the structure of English mnemonic lexicon: their limited potential as regards direct nomination of specific stages of mnemonic processing is compensated with their ability to manifest memory content in general, not specifying particular operations it is subjected to.

Finally, the least autonomous component of English mnemonic lexicon includes memory nominals. Despite their systematic memory-related meanings registered in dictionaries, nouns and adjectives constituting this group are not capable of transmitting mnemonic content as freely and on the scale as large as memory verbs, collocations, and even non-mnemonic lexis can. As it has been mentioned above, the number of nouns in this group counts seven items, however, none of them can function as an independent memory marker. In accordance with the language data, the noun memory has the highest potential in this regard, however, its broad semantics results in functional limitations that do not allow nominating a memory process directly and require that specifiers be used. The other nouns in this group are also limited in their potential to represent memory operations as their semantic structure reflects only one mnemonic operation - memory retrieval. Besides that, two of the lexical units on the list render additional evaluative connotations.

Adjectival constituents of the semantic group under consideration are subject to yet more salient restrictions as they can mark only one or two mnemonic processes, which makes them supplementary lexical devices participating in transmitting of mnemonic meanings as specifiers or amplifiers but not as primary verbalizers.

An obvious consequence of the abovementioned functional limitations affecting the semantic group of nominals systematically expressing memory-related meanings in English is that memory nouns and adjectives are found mostly in communicative contexts in which the mnemonic process being verbalized is explicitly marked by other lexical devices. Therefore, the primary role of these lexemes in communication is to introduce or support the general memory theme initiated by the speaker, not naming any specific processes, and thus provide for the topical coherence of memory reports and delimitation of their borders in the communication flow. 
As suggested by the language data, in terms of their verbalization potential, two types of components constituting English mnemonic lexicon can be differentiated: autonomous and non-autonomous. Autonomous constituents are capable of expressing mnemonic processes independent of any other lexical devices. They include memory verbs as primary direct verbalizers and memory collocations that do not nominate mnemonic operations directly; yet they can still function as lexical verbalizers not relying on any lexical adjuncts semantically associated with memory. Non-autonomous constituents can be seen as lacking verbalization potential and dependent on contextual satellites when conveying mnemonic content. This component of English mnemonic lexicon is represented by memory nominals characterized by a very limited lexicalization power. Non-mnemonic lexis associated with memory via metonymy occupies a transitional position between the autonomous and non-autonomous constituents. On the one hand, some of its members may objectify memory operations. On the other hand, their number is not vast, while most other members have to rely on supporting lexical elements.

It cannot go unnoticed that there is no direct correlation between the semantics of a lexical unit and its potential regarding representation of mnemonic meanings. Unexpectedly, memory nominals systematically expressing memory-related meanings play a more modest role in communicating mnemonic content than verb collocations that are not direct lexicalizers of memory. A possible explanation is that even having memory-associated semantics, their meanings are broader than those of memory verbs, thus, determining their dependence on adjunct lexical elements.

Another problem being solved in this stage of the study concerns the degree of objectifying mnemonic processing stages on the lexical level. According to the language data, storing and retrieval are two memory processes that are lexicalized most explicitly in English via five direct lexical verbalizers, verb collocations, and non-mnemonic lexis. Loss of information can be directly expressed by four memory verbs, verb collocations, and non-mnemonic lexis as well. Finally, the process of encoding is characterized by the lowest number of lexical markers and finds its verbal reflection only in two verbs and verb collocations. Memory nominals, as it has already been stated, do not take part in objectifying mnemonic processes explicitly, functioning as supporting lexical markers. 
These results could suggest that direct lexicalization of mnemonic processes may correlate with the extent of their significance to individuals in English-speaking cultures. Therefore, storing and retrieval may be seen by English-speaking natives as the most important steps in the cognitive processing of incoming information.

\section{Lexicalization patterns and their salience attribution}

The final stage of the present research focused on identifying recurrent lexicalization patterns used to verbalize mnemonic experiences. For this purpose, language samples registered in the corpus were scanned for lexemes that could be seen as at least one of the semantic groups constituting English mnemonic lexicon. Results obtained while examining the language samples yielded the following patterns:

Pattern 1: Memory verb

Pattern 2: Memory verb + supporting memory nominal

Pattern 3: Memory verb + memory collocation

Pattern 4: Memory verb + non-mnemonic lexis used metonymically

Pattern 5: Memory verb + non-mnemonic lexis used metonymically+ supporting memory nominal

Pattern 6: Memory verb + memory collocation + supporting memory nominal

Pattern 7: Memory verb + memory collocation + non-mnemonic lexis used metonymically

Pattern 8: Memory verb + memory collocation + non-mnemonic lexis used metonymically + supporting memory nominal

Pattern 9: Memory nominal (or a combination)

Pattern 10: Memory collocation

Pattern 11: Memory collocation + supporting memory nominal

Pattern 12: Memory collocation + non-mnemonic lexis used metonymically

Pattern 13: Memory collocation + non-mnemonic lexis used metonymically + supporting memory nominal

Pattern 14: Non-mnemonic lexis used metonymically

Pattern 15: Non-mnemonic lexis used metonymically + supporting memory nominal

Pattern 1 is illustrated by Example 3 above in which the single memory verb to remember explicitly names the process of storing information in memory. This pattern 
may have several realizations. For instance, in (4) and (5) the verb to remember is repeated twice. In Example 2 three memory verbs to remember, to forget, and to unforget are employed to convey mnemonic meanings.

Pattern 2 is activated in (16) in which the memory verb to remember combines with the mnemonic noun memory, the former being repeated three times and the latter being repeated twice.

Pattern 3 is exemplified in fragment (8) above, being lexically represented by the combination of the memory verb to recall used with a negator to express forgetting and the verb-equivalent collocation to have no memory also expressing loss of information.

Pattern 4 can be found in Example 6 illustrating the use of the perception verb to see expressing a general cognitive activity and the verb to remember denoting memory retrieval.

Pattern 5 is different from the four patterns above in the number of lexical devices involved in manifestation of memory operations. In Pattern 5 three lexical markers are combined: a memory verb, non-mnemonic lexis used metonymically, and a supporting memory nominal. Example (23) below demonstrates this pattern at work. The prospective memory content presented in the monologue is explicitly marked with the memory verbs to forget, to remember, and to recollect, the mental verb to think, and the noun memory.

(23) Jimmy Thomas, my loving husband, I will never forget you. I will be remembering you when I see lovers holding hands in early spring. I will think of you when I see a baby smile. And because of you, my heart will be invigorated with each rise and set of every radiant sun. Yes, I will be remembering you at the beginning of each day and for its duration. Because of you, I will have the peace to sleep through troublesome nights. Oh Jimmy, my husband, come every lazy, Sunday morning, I will be recollecting memories about you and me. I will think of you when I'm just thinking. Oh you, you, my perfect lover, I will be remembering you when I hear songbirds paying homage to life. Oh, I will not forget your warm, sweet kisses that we shared on those cold dreary winter nights. And when I listen to my heart, I know I will hear your laughter. I will enjoy your soft words of wisdom as they sooth my insecurity. And each rising morning and setting evening, I will revisit your words that said with clarity, 'I love you, Annie.' My husband, my only lover, I will always be remembering and wanting your love through all the days of the seasons. When leaves fall from the trees in early fall, and new and vibrant ones replace them, I will be longing for your soft touch. I somehow hoped that our story would never have ended, at least, not like this. But, I know I must go on. Our perfect memories 
will become my partner for a lifetime. And I will nurture them with pride, love, and kindness. I will take comfort in knowing that my empty arms will hold you again, and this time, I know it will be for all eternity." (Casteel, 2009)

Pattern 6 can be observed in (24) below representing the communicative situation of memory retrieval which is manifested on the lexical level with the help of the memory verb to forget, the verb-equivalent collocation to unleash memories and the mnemonic noun flashbacks.

(24) You try to forget, then without any warning something you hear, see or smell unleashes the memories: fear, panic and then profound sadness soon follow. And yet I was aware that my flashbacks, mercifully few and far between, provide only a fleeting glimpse into the enormous suffering of hundreds of thousands of victims and survivors. (Sunga, 2016)

Example (25) illustrates the way Pattern 7 is activated in the communicative situation of memory retrieval. In the text below, which is a reader's comment to the discussion related to the article Why can't I remember Mum? on the Guardian website, the process of restoring information from memory is directly expressed by the memory verb to remember and the verb-equivalent collocations to have memories and to have recollection. A supporting lexical marker also presupposing a reconstructive cognitive activity is expressed by the verb to visualize, which is a constituent of the thematic group of mental processes within the larger group of non-mnemonic lexis used metonymically.

(25) My mum died when I was 20 and I also have no real memories of her, indeed, I have very few memories of my entire childhood. Sometimes when I do try to remember things, I end up visualising something that is actually a photograph. It's very odd. It's horrible because it's just this massive blank in my life and when people ask me things I find myself repeating stories I've been told or recreating what I've seen in photographs.

Occasionally I can smell her very vividly. I can't remember what she sounds like though. I rarely dream about her, and when I do, she always announces that she's dead. I don't like it at all and prefer not to dream about her.

I can't decide whether it's a good thing I have very little recollection of her or a bad thing, it just feels like she was never really here at all.

Anyway, thank you for sharing this, it's been a huge comfort, and of course, am very sorry for your loss. (Beales, 2010)

Pattern 8 is the most extended one, including all four possible types of lexical markers, that is, a memory verb, a verb-equivalent collocation, non-mnemonic lexis, and 
a memory nominal. Example (26) illustrates its activation in the communicative situation of retention, specifically, the fragment discusses the earliest mnemonic experiences the individual is aware of. The process of keeping information in memory is directly nominated by the memory verb to remember and an equivalent construction to have a memory, the latter being used with a negator to demonstrate an undesirable result of storing in memory. The noun memory also explicitly marks a verbal product of cognitive processing while the supporting lexical marker mind belonging to the thematic group of mental activity lexemes in combination with the verb of retention to imprint accentuate the subject's focus on memory sharing.

(26) My earliest memory is a suitably vivid and somewhat gothic one from when I must have been around 18months old. I toddled into my grandmother's kitchen to find the tiny but extraordinarily terrifying matriarch of the family standing at the sink skinning a rabbit.

And I think the main reason why this was so powerfully imprinted on my mind apart from the obvious shock of seeing a knife wielding bloodthirsty granny - was the smell. I've asked cooks about this and apparently the odour of skinned rabbit can be very pungent. Also, I remember the skin having a greenish tint but I am not sure if that's just been blurred by time. Truth is that was the first and last time I have ever got close to rabbit skinning so have never been able to confirm any further details!

Alas, I have no memory of what dish Nan ended up producing from it. I trust it was a tasty stew :) (Saner et al., 2018)

Pattern 9 being, on the contrary, structurally minimalistic and including only a memory nominal or nominals, is represented in (27) below. A peculiar feature of Pattern 9 is predetermined by the semantics of its pattern-forming lexical elements and consists in its inability to nominate a specific mnemonic process since memory nominals stand out from the cohort of other memory-associated lexical units due to their functional deficiency in this regard.

(27) My Christmas brain is similarly selective about which childhood shopping memories it will allow. The first trip of the year to see Fenwick's Christmas window in Newcastle is in, followed by long, attentive study of the fragile, inky pages of the Argos catalogue (a treasure map of the adventures ahead). Finally there are my reminiscences of what was then Europe's biggest mall - the MetroCentre, Gateshead. It contained a faux-Victorian town square, a funfair, a fence made of giant pencils and indoor fountains full of sparkling pennies made shiny by the nostril-stinging chemicals in the water. Paradise. (Laverne, 2014) 
Pattern 10 finds its illustration in Example (15) which represents the subject's utterance in the situation of memory loss. The relevant mnemonic process is lexically manifested with the help of a verb-equivalent collocation synonymous to the verb to forget.

The application of Pattern 11 can be found in (28) below. In the statement made by the subject of mnemonic experience, the process of storing information in memory is represented by the verb-equivalent collocation to have memories while the supporting memory nominal forgetful does not indicate a specific process but rather points at a memory-related personal quality.

(28) I am forgetful but have memories from 80 years ago. What's going on?

\section{(Liggett, 2019)}

Example (18) above demonstrates a sample representing Pattern 12. The pattern is based on two pattern-forming lexical elements: a verb-equivalent collocation (in case of the fragment under consideration it is to have a vague memory) and a non-mnemonic lexical unit used metonymically (in the extract above this component is represented by the noun mind that belongs to the thematic group of mental activity).

Pattern 13 is illustrated by (29) below. The fragment presents a linguistic reflection of the communicative situation of memory retrieval. The relevant process is explicitly specified by the verb-equivalent collocation to get a flashback that stresses the involuntary nature of remembering. The non-direct lexical markers of mnemonic processing are the semantically relevant noun memory and metonymically used mental noun brain.

(29) This would be a nightmare. I really hate it when you get a cringe flashback of something stupid you did or said 20 or 30 years previously. I wish those memories could be burnt out of the brain. (Dahl, 2018)

Pattern 14 has a peculiarity that makes it unique among the rest of the lexicalization patterns under discussion. It does not include any memory-related lexemes either directly nominating a mnemonic process or implicitly pointing at one. The lexical element performing the pattern-building function in case of Pattern 14 is a non-mnemonic lexical unit belonging to one of the thematic groups outlined in Section 1.3 above. For instance, Example (19) represents the subject's utterance in the situation of memory retrieval. On the lexical level the relevant process is marked with the help of 
the perception verb to look with an adverb of reverse action in postposition. The temporal distance between the moment of memory retrieval and the period being reconstructed is additionally accentuated by the retrospective adjective past.

Pattern 15 is activated in Examples (17) and (20) above. Its structure is constituted by two secondary memory lexicalizers: a non-mnemonic lexical unit used metonymically and a supporting memory nominal. For instance, in (20) the first component is represented by a translocation verb to take back and an emergence verb to flood back, both expressing memory retrieval. The noun memories functions as a supporting element, pointing at mnemonic content in general.

Analysis of the fifteen patterns differentiated in the present study allows the following conclusions regarding lexical representation of memory processes in English:

1. Lexicalization of memory in English is based on a number of recurrent patterns that can be classified and described according to their structural organization.

2. Any of the constituents of English mnemonic lexicon can perform the role of the pattern-building element, that is, be strong enough to verbalize memory processes on its own in a relevant communicative situation. In such cases mnemonic content is conveyed in an utterance with a single lexical memory marker. Most patterns, however, are based on combinations of multiple lexical devices expressing memory meanings.

3. Constituents of English mnemonic lexicon can be freely combined in order to communicate memory meanings. The pattern-based structure of memory utterances in English allows for modifications that mostly consist in a repetition of a lexeme or constituent element.

4. In communication the opposition between semantically autonomous and nonautonomous lexis is neutralized as the two categories of lexical units characterized in the previous section as non-autonomous and transitional between autonomous and non-autonomous lexis due to their meanings expressing memory processing in general and not related to memory respectively, are still capable of transmitting mnemonic content and specifying memory operations. The most likely explanation for this fact seems to be the contextual effect, the communicative situation being the key factor modifying, specifying and amplifying the meaning of non-autonomous lexical markers. 


\section{Conclusion}

This research was specifically aimed at examining the lexical component of the verbal code representing the mnemonic faculty in English and the sphere of cognitive processing in general which, to the best of our knowledge, has not yet merited an in-depth systematic analysis either in works on cognitive linguistics or in linguistic memory studies. As this domain opens a broad avenue for further investigation that will require joined efforts on the part of linguists, in the present paper our focus was specifically on the lexical level of memory encoding and lexicalization patterns in English.

The results show that English has an extensive set of lexical devices marking the mnemonic faculty in verbal communication. This set demonstrates properties of systematic organization, which reveals itself in the use of regular recurrent patterns for conveying memory meanings. The fifteen patterns differentiated in accordance with the language data are based on pattern-building components of the lexical code marking memory reports in English. The said components include 1) memory verbs, 2) verbequivalent memory collocations, 3) memory nominals, and 4) non-mnemonic lexis used metonymically.

Memory verbs and verb-equivalent memory collocations are primary verbalizers of the mnemonic function in English, and they form the nucleus of the English mnemonic lexicon. The non-mnemonic lexis and memory nominals function as secondary verbalizers, and they constitute the proximal and far periphery respectively. As suggested by the language data, memory verbs and verb-equivalent collocations have the highest potential regarding verbal representation of mnemonic processes and therefore can be seen as autonomous memory verbalizers capable of communicating mnemonic content without any supplementary linguistic devices, such as specifiers or amplifiers. In this quality they should be considered a macrogroup of lexical units systematically expressing memory meanings and being the core of English mnemonic lexicon.

Empirical evidence allows differentiating the following functions of the lexical component of the linguistic memory code: 1) mnemonic lexicon signals the engagement of the mnemonic faculty in general without referring to any specific stage of memory processing; 2) mnemonic lexicon explicitly nominates phases of memory processing and presents its results; 3) mnemonic lexicon registers the nature of mnemonic processing and manifests the memory agent's response to initiation of a mnemonic process. 
Thus, the results yielded by this investigation expand our current knowledge in the sphere of lexicalization of mnemonic content in English and are in line with the oneto-many concept describing basic principles of representing cognitive structures.

\section{Limitations and Future Research}

Although our findings have certain implications for linguistic memory studies and can be extrapolated to other cognitive faculties, they are still not devoid of a number of limitations resulting mostly from the composition of the language corpora under examination.

One limitation is related to the collection of data without respect to the gender and age of the memory agent producing a mnemonic utterance. Future research should investigate the role of these two factors on the choice of specific language means to represent mnemonic processes as it may shed light on the development of memoryrelated verbal competence with age and reveal if there are any gender-conditioned preferences regarding the choice of specific lexical devices. The presented findings may also have implications for the design of research procedures used by cognitive psychologists to study the development of memory-related language use in different age groups.

Despite the fact that the collected data were quite diverse with respect to genres and communication channels, the sources of empirical evidence were rather homogeneous as regards the discourse type (the corpora included samples of mass media and social media discourse, public and political discourse, autobiographical discourse and fiction), thus limiting the generalizability of the conclusions to other types of discourse. Future research should address and encompass other discourse varieties of present-day English, such as, for example, legal, medical and education discourses.

Another venue to explore in future studies of memory language is the cultural factor. Drawing on the idea presented in (Schwanenflugel, Martin, Takashi 1999, p. 813) that a typical approach to assessing the theory of mind held by a particular cultural group consists in studying the language used by group members to speak about mental activities, we suggest that prospective research of mnemonic lexicon should focus on its cultural and cross-cultural variation. 
As a conclusion, we emphasize the importance of further investigation into mnemonic lexicon in cognitive, social, cultural and linguistic aspects for a more profound understanding of how languages reflect and what they reveal about the cognitive sphere.

\section{References}

Sources of language samples have been marked with an asterisk. *

* Abbott, M. (2014, February 8). The Virgins by Pamela Erens - review. The Guardian. https:/ / www.theguardian.com/ books/2014/ feb/ 08/ virgins-pamela-erensreview

* Adams, T. (2018, November 11). We properly honour the past when we remember in new and vital ways. The Guardian. https:/ / www.theguardian.com/ commentisfree/ 2018/ nov/ 11/ we-properlyhonour-the-past-when-we-remember-in-new-and-vital-ways

Amberber, M. (2007). The Language of Memory in a Crosslinguistic Perspective. John Benjamins Publishing. https:// doi.org/10.1075/hcp.21

Assmann, J. (1995). Collective Memory and Cultural Identity. New German Critique, 65, 125-133. https:// doi.org/10.2307/488538

Assmann, J. (2008). Communicative and Cultural Memory. In Erll, A., \& Nünning, A. (Eds.). Cultural Memory Studies: An International and Interdisciplinary Handbook. de Gryuter (pp. 109-118).

Atkinson, R.C., \& Shiffrin, R. (1968). Human memory: A proposed system and its control processes. In Spence, K. \& Spence, J. T. (Eds.) The Psychology of Learning and Motivation: Advances in Research and Theory, 2 (pp. 90-195). Academic Press. https:// doi.org/ 10.1016/ S0079-7421(08)60422-3

* Bakare, L. (2018, October 1). Mad Men. The Guardian. https:/ / www.theguardian.com/tv-and-radio/2018/ oct/ 01/ matt-weiner-onsexual-harassment-allegation-i-really-dont-remember-saying-that

Baddeley, A. (1986). Working Memory. Oxford University Press.

Barančeeva, E. I. (2014). Osobennosti verbalizacii processov pamjati: leksikografičeskie ramki i diskursivnaja reprezentacija [Verbalization features of memory processes: lexicographical limits and discourse representation]. Vestnik Novosibirskogo gosudarstvennogo pedagogičeskogo universiteta [Novosibirsk State Teachers' Training University Bulletin], 4(20), 114-123.

* Beales, S. (2010, September 25). Why can't I remember Mum? The Guardian. https:/ / www.theguardian.com/ lifeandstyle/ 2010/ sep/ 25/ memory-mothercancer 
Bellinger, M. (2010). Weblogs as Autobiographical Discourse. Anthós, 2(1): Article 2. https:// doi.org/ 10.15760/ anthos.2010.19

Bierwisch, M., \& Schreuder, R. (1992). From concepts to lexical items. Cognition, 42(1-3), 23-60. https:/ / doi.org/ 10.1016/ 0010-0277(92)90039-K

Bondareva, L.M. (2014). Retrospektivnyj diskurs kak transljator kul'turnoj pamjati [Retrospective discourse as a means of transmitting cultural memory]. In Ševčenko, V.D. (Ed.), Jevoljucija i transformacija diskursov: Jazykovye, filologičeskie i sociokul'turnye aspekty [Evolution and transformation of discourses: Linguistic, philological and sociocultural aspects], (pp. 136-142). Samarskij gosudarstvennyj universitet.

Bragina, N.G. (2007). Pamjat'v jazyke i kul'ture [Memory in language and culture]. Jazyki slavjanskih kul'tur.

Brockmeier, J. (2000). Autobiographical time. Narrative Inquiry, 10(1), 51-73.

Brockmeier, J. (2015). Beyond the Archive: Memory, Narrative, and the Autobiographical Process. Oxford University Press.

https:/ / doi.org/ 10.1093/ acprof:oso/ 9780199861569.001 .0001

Brockmeier, J. (2018). From Memory as Archive to Remembering as Conversation. In Wagoner B. (Ed.). Handbook of Culture and Memory (pp. 41-64). Oxford University Press. https:// doi.org/ 10.1093/ oso/ 9780190230814.003 .0003

Bruner, J. (1991). The narrative construction of reality. Critical Inquiry, 18(1), 1-21.

* Busfield, S. (2007, May 10). How will you remember Tony Blair? The Guardian. https:// www.theguardian.com/politics/ blog/2007/ may/ 10/ howwillyoure

Burima, M. (2010). Memory narrative waves in the $20^{\text {th }}$ century Latvian literature. Comparative Studies. The Memoirs of the $20^{\text {th }}$ Century: Nordic and Baltic Experience, 3(2), 49-60.

* Carlyle, R. (1999). Antonia Bird interview. The Guardian. Retrieved from: https:/ / www.theguardian.com/ film/ Guardian NFT/ interview/ 0,71615,00.html

* Casteel, C. A. (2009). A Lady's Heart and Soul: My Life as a Colored - Negro - BlackAfrican - American. AuthorHouse.

Chafe, W. (1973). Language and Memory. Language, 49(2), 261-281. https:// doi.org/ 10.2307/412454

* Clark, A. (2010, April 20). Ex-Lehman Brothers boss Dick Fuld denies using accounting 'gimmick'. The Guardian. Retrieved from: https:// www.theguardian.com/ business/2010/apr/ 20/ dick-fuld-lehman

Cohn, D.C. (1983). Transparent Minds. Narrative Modes for Presenting Consciousness in Fiction. Princeton University Press. 
* Cope, W. (2014, November 15). Wendy Cope: 'I remember getting angry with my sister...' The Guardian. Retrieved from:

https:/ / www.theguardian.com/lifeandstyle/ 2014/ nov/ 15/ wendy-cope-recallschildhood-memories

* Cooke, E. (2015, November 7). Let a grandmaster of memory teach you something you will never forget. The Guardian. Retrieved from:

https:// www.theguardian.com/ education/2015/ nov/ 07/ grandmaster-memoryteach-something-never-forget

Craik, F. I.M., \& Lockhart R.S. (1972). Levels of processing: A framework for memory research. Journal of Verbal Learning and Verbal Behavior, 11, 671-684.

https:// doi.org/ 10.1016/ S0022-5371(72)80001-X

* Dahl, M. (2018, May 13). The unexpected benefits of cringing. The Guardian. Retrieved from: https:/ / www.theguardian.com/ global/2018/ may/13/ the-unexpectedbenefits-of-a-good-cringe-social-embarrassment-melissa-dahl

Erll, A. (2011). Memory in Culture. Palgrave Macmillan. https:// doi.org/ 10.1057/9780230321670

Filipović, L. (2007). Talking about motion: A crosslinguistic investigation of lexicalization patterns. John Benjamins. https:/ / doi.org/ 10.1075/ slcs.91

Fillmore, Ch. (1975). An alternative to checklist theories of meaning. In C. Cogen, H. Thompson, G. Thurgood, K. Whistler, J. Wright (Eds.), Proceedings of the First Annual Meeting of the Berkeley Linguistics Society, 1,123-131. https:// doi.org/ 10.3765/ bls.v1i0.2315

Fivush, R. (1999). The Stories We Tell: How Language Shapes Autobiography. Applied Cognitive Psychology, 12(5), 483-487.

Fivush, R. \& Nelson, K. (2004). Culture and Language in the Emergence of Autobiographical Memory. Psychological Science, 15(9), 573-577. https:// doi.org/ 10.1111/j.0956-7976.2004.00722.x

* French, Ph. (2000, November 26). This movie changed my life. The Guardian. Retrieved from: https:/ / www.theguardian.com/ observer/ screen/ story/ 0,6903,402848,00.html

Gasparov, B. (2010). Speech, Memory and Meaning: Intertextuality in Everyday Language. de Gruyter. https:// doi.org/ 10.1515/9783110219111

* Gates, Ph. (2003, April 24). Country Diary. The Guardian. Retrieved from: https:/ / www.theguardian.com/ uk/ 2003/ apr/ 24/ ruralaffairs

Gaus, K. \& Riabova, M. (2019). Kognitivnyj scenarij verbalizacii koncepta threat v mediadiskurse (na materiale vyskazyvanij D. Trampa) [Cognitive Script of Verbalization of Concept "Threat" in Media Discourse (as Exemplified in D. Trump's Statements)]. Vestnik Kemerovskogo gosudarstvennogo universiteta 
[Bulletin of Kemerovo State University], 21, 164-170.

https:/ / doi.org/ 10.21603/ 2078-8975-2019-21-1-164-170

Goddard, C. (2010). Universals and variation in the lexicon of mental states. In Malt, B. C. \& Wolff, P. (Eds.). Words and the world: How words capture human experience. Oxford University Press.

https:/ / doi.org/ 10.1093/ acprof:oso/ 9780195311129.003.0005

Golajdenko, L.N. (2012). Prilagatel'nye so značeniem pamjati / vospominanija i ih funkcionirovanie $\mathrm{v}$ hudožestvennoj proze [Adjectives denoting memory / recollections and their functioning in fiction prose]. Vestnik Čljabinskogo gosudarstvennogo pedagogičeskogo universiteta [Čeljabinsk State Teachers' Training University Bulletin], 8, 205-215.

* Gould, W. (2018, December 24). What It's Really Like To Be A Professional Christmas Caroler. The Huffpost. Retrieved from: https:// www.huffpost.com/ entry/ professional-christmascaroler n 5c1d1d78e4b0407e907a8a81

Gray, P. (2010). Psychology. Worth Publishers.

Haden, C.A., \& Wilkerson, E. (2010). Enhancing Building, Conversation, and Learning Through Caregiver-Child Interactions in a Children's Museum. Developmental Psychology, 46(2), 502-515. https:// doi.org/10.1037/a0017822

Halbwachs, M. (1992). On Collective Memory. The University of Chicago Press.

Halbwachs, M. (1997). La mémoire collective. Editions Albin Michel S.A.

Hedrick, A.M. Haden, C.A., \& Ornstein, P.A. (2009). Elaborative Talk During and After an Event: Conversational Style Influences Children's Memory Reports. Journal of Cognition and Development, 10(3), 188-209.

* Herreria Russo, C. (2018, September 18). Mark Judge, Key Witness To Alleged Brett Kavanaugh Assault, Refuses To Testify. The Huffpost. Retrieved from: https:// www.huffpost.com/ entry/ mark-judge-testify-kavanaughhearing_n_5ba15f8ae4b04d32ebfd8c01

Hirsch, M. (2008). The Generation of Postmemory. Poetics Today, 29(1), 103-128. https:// doi.org/ 10.1215/03335372-2007-019

Hirst, W. \& Echterhoff, G. (2012). Remembering in conversations: The social sharing and reshaping of memories. Annual Review of Psychology, 63, 55-79. https:// doi.org/ 10.1146/ annurev-psych-120710-100340

* Hornbacher, M. (1999). Wasted: a memoir of anorexia and bulimia. Harper Perennial.

Howe, M.L., \& Courage, M.L. (1997). The emergence and early development of autobiographical memory. Psychological Review, 104, 499-523. 
* Is it possible to remember being born? (n.d.). The Guardian. Retrieved from: https:/ / www.theguardian.com/ notesandqueries/ query/ 0,5753,-2899,00.html

Iskhakova, R.F. \& Khomjakova E.G. (2009). Pamjat' i vosprijatie: nekotorye aspekty jazykovoj reprezentacii [Memory and perception: aspects of verbal representation]. Vestnik Sankt-Peterburgskogo universiteta [St. Petersburg University Bulletin], Series 9, 1(1), 84-88.

* Jeffries, S. (2014, July 1). Are you wasting money on direct debits you've forgotten about? The Guardian. Retrieved from:

https:// www.theguardian.com/ money/ shortcuts/2014/ jul/ 01/ are-youwasting-money-on-direct-debits

* Kazmir, M. (2017, September 21). Valerie Plame Can Claim Whatever She Wants, But Her Anti-Semitism Is Clear As Day. The Huffpost. Retrieved from: https:/ / www.huffpost.com/ entry/ valerie-plame-can-claim-whatever-shewants-but-her_b_59c43736e4b0b7022a646944

* Kinsella, S. (2010). Twenties Girl. Dial Press Trade Paperback.

Klein, K. (2000). On the Emergence of Memory in Historical Discourse. Representations 69, 127-150. https:/ / doi.org/ 10.1525/ rep.2000.69.1.01p0064y

* Kucheran, K. (2019, November 8). I Was Spending 5 Hours A Day On My Instagram Obsession And It Ruined My Life. The Huffpost. Retrieved from: https:// www.huffpost.com/ entry/ instagramaddiction n 5c34c539e4b0116c11f092dd

Labov, W. \& Waletzky J. (1966). Narrative analysis: Oral versions of personal experience. In J. Helm (Ed.), Essays on the Verbal and Visual Arts. Proceeding of the 1966 Annual Spring Meeting of the American Ethnological Society, (pp. 12-44). University of Washington Press.

Lakoff, G. \& Johnson, M. (1980). Metaphors We Live By. University of Chicago Press.

Langacker, R.W. (1991). Foundations of Cognitive Grammar. Vol. II: Descriptive Application. Stanford University Press.

* Laverne, L. (2014, November 23). Lauren Laverne: 'It might be gauche to love Christmas, but I'm afraid I just do it'. The Guardian. Retrieved from: https:/ / www.theguardian.com/lifeandstyle/ 2014/ nov/ 23/it-might-be-gaucheto-love-christmas-but-i-do

* Lawn, C. (2017, October 24). New Opportunities for Women of Color From Connie Lawn and Kehli Cage. The Huffpost. Retrieved from: https:// www.huffpost.com/ entry/ new-opportunities-for-women-of-color-fromconnie-lawn b 59efd9cbe4b00a4ce5a22284

* Leaf, C. (2002, October 18). JOURNEYS; Peace, Calm... Then Thwack! The New York Times. Retrieved from: 
https:/ / www.nytimes.com/2002/10/18/ travel/ journeys-peace-calm-thenthwack.html

Lehmann, C. (1990). Towards Lexical Typology. In W. Croft, K. Denning, \& S. Kemmer (Eds.) Studies in Typology and Diachrony (pp. 161-185). John Benjamins. https:// doi.org/ 10.1075/ tsl.20.11leh

Levin, B. \& Rappaport Hovav, M. (2019). Lexicalization Patterns. In R. Truswell (Ed.). Oxford Handbook of Event Structure (pp. 395-425). Oxford University Press. https:// doi.org/ 10.1093/ oxfordhb/ 9780199685318.013 .18

* Liggett, E. (2019, April 9). I am forgetful but have memories from 80 years ago. What's going on? The Guardian. Retrieved from: https:/ / www.theguardian.com/ lifeandstyle/ 2019/ apr/ 09/ forgetful-memoriesyears-notes-queries

* Litt, T. (2010, May 23). Once upon a life: Toby Litt. The Guardian. Retrieved from: https:// www.theguardian.com/lifeandstyle/2010/ may/ 23/ toby-litt-pragueenglish-teacher

Loftus, G. R., \& Loftus E.F. (1975). Human Memory: The Processing of Information. Halsted Press.

Majid, A. \& Enfield, N. \& Staden, M. (2006). Parts of the body: cross-linguistic categorization. Language Sciences, 28 (137-147). https:// doi.org/ 10.1016/j.langsci.2005.11.001

Malt, B. \& Gennari, S. \& Imai, M. (2010). Lexicalization Patterns and the World-to-Words Mapping. Words and the Mind: How Words Capture Human Experience. Oxford: Oxford University Press. https:/ / doi.org/ 10.1093/ acprof:oso/ 9780195311129.003.0003

Maslova, V.A. (2001). Lingvokul'turologija [Linguistic Culture Studies]. Akademija.

Mlynář, J. (2014). Language and Collective Memory: Insights from Social Theory. Slovak Journal of Political Sciences, 14(3), 217-236.

Morimoto, S. (2016). A Lexical Network Approach to the Acquisition of English Verbs of Memory: The Case of Japanese Learners. Vocabulary Learning and Instruction, $5(1), 1-17$.

Njubina L.M. (2013). Memuarnyj tekst kak "kul'turogennyj” fenomen [Text of memoirs as a "culturegenic" phenomenon]. Izvestija Smolenskogo gosudarstvennogo universiteta [Smolensk State University Bulletin], 2(22), 85-97.

Njubina, L.M. (2008), Pamjat', vospominanija i tekst [Memory, reminiscence and text]. Izvestija Smolenskogo gosudarstvennogo universiteta [Smolensk State University Bulletin], 4, 12-28.

Ogorodnikova, L.A. (2012). Podhody k issledovaniju pamjati i mnemičeskih sposobnostej v otečestvennoj i zarubežnoj psihologii [Approaches to studying 
memory and mnemonic faculties in Russian and foreign psychology]. Jaroslavskij pedagogičeskij vestnik [Yaroslavl Pedagogical Bulletin], 2, 308-312.

Paganoni, M.C. (2011). Blogging 9/11 and Memory Discourse. Altre modernità. Numero Speciale 9/11/2011, 279-294.

* Piazza. L. (2019, February 25). I Spent 4 Weeks Near Death In The ICU. Here's What I Learned Struggling For My Life. The Huffpost. Retrieved from: https:/ / www.huffpost.com/ entry/ near-death-icu n 5c6efd0ae4b0e2f4d8a3ecf1

Potter, J. \& Wetherell M. (1987). Discourse and Social Psychology. Beyond Attitudes and Behaviour. SAGE.

Raffaelli, I. \& Chromý, J. \& Kopecka, A. (2019). Lexicalization patterns in color naming in Croatian, Czech, and Polish. John Benjamins. https:// doi.org/10.1075/ sfsl.78.12raf

* Ratcliffe, R. (2013, August 15). How I did in my A-levels - by people who made it in life anyway. The Guardian. Retrieved from:

https:/ / www.theguardian.com/ education/ 2013/ aug/ 15/a-level-results-daymemories

Rebrina, L.N. \& Milovanova M.V. (2015). Reprezentacija prostranstva pamjati glagol'nymi kollokacijami v rossijskih SMI [Verbal collocations as means of representing memory space in Russian media]. V mire naučnyh otkrytij [In the world of scientific discoveries], 7.8(67), 3031-3042.

Rebrina, L.N. (2014). Avtobiografičeskaja pamjat' kak diskursivnyj fenomen (na materiale nemeckogo jazyka) [Autobiographical Memory as a Discursive Phenomenon (as Exemplified in German)]. Vestnik Leningradskogo gosudarstvennogo universiteta im. A.S. Pushkina [Leningrad A.S. Pushkin State University Bulletin], 1(4), 141-142.

Rebrina, L.N. (2008). Leksičeskie sredstva reprezentacii operacij pamjati v nemeckom jazyke: principy lingvističeskogo analiza [Lexical means of representing mnemonic operations in German: principles of linguistic analysis]. Vestnik Volgogradskogo Gosudarstvennogo Universiteta. Ser. 2: Jazykoznanie [Volgograd State University Bulletin, Series 2: Linguistics], 2, 112-118.

* Reminiscent / Definition of Reminiscent by Oxford Dictionary on Lexico.com also meaning of Reminiscent. Lexico Dictionaries | English. (2020). Retrieved 6 June 2020, from https:// www.lexico.com/ definition/ reminiscent

Ricoeur, P. (2004). Memory, History, Forgetting. University of Chicago Press. https:// doi.org/10.7208/ chicago/ 9780226713465.001 .0001

Rogačeva, J. (2003). Reprezentacija frejma "pamjat'” v sovremennom anglijskom jazyke (Na materiale glagol'noj leksiki) [Representation of the memory frame in modern English (a study of verbal lexis)]. Doctoral thesis. Belgorod State University. 
* Russell, A. (2018, November 23). I Spent Thousands Feeding My Compulsive Shopping Addiction. Here's How I Stopped. The Huffpost. Retrieved from: https:// www.huffpost.com/ entry/ compulsive-shoppingaddiction n 5bf4235fe4b01909c809b32d

* Saner, E., Toynbee P., Aly, R., Moss, S., Cartner-Morley, J., Freeman, H., Parkinson, H.J., Grace, J., Muir, H., Phillips, S., Perkins, A., Noor, P. \& Hattenstone, S. (2018, July 19). Sunflowers and Santa Clause: Guardian writers and readers on how their first memory changed them. The Guardian. Retrieved from: https:// www.theguardian.com/ science/ 2018/jul/ 19/ sunflowers-and-santaclaus-guardian-writers-and-readers-on-how-their-first-memory-changed-them

Schank, R.C. \& Abelson, R. P. (1995). Knowledge and Memory: The Real Story. In R.S. Wyer Jr. (Ed.), Knowledge and Memory: The Real Story (pp. 1-85). Hillsdale.

Schwanenflugel, P.J., Martin M., \& Takahashi T. (1999). Evidence for cultural commonality and variation in theory of mind. Memory \& Cognition, 27(5), 813825. https:// doi.org/ 10.3758/ BF03198534

Schwartz, B.L. (2013). Memory: Foundations and Applications. SAGE.

Sereda, G.K. (1985) Čto takoe pamjat'? [What is memory?] Psikhologičeskij žurnal [Journal of Psychology], (6)6, 41-48.

* Sharp, Z. (2011). Fifth Victim. Allison \& Busby.

* Sieczkowski, C. (2017, October 30). 'House Of Cards' Creator Responds To Kevin Spacey Sexual Harassment Allegations. The Huffpost. Retrieved from: https:/ / www.huffpost.com/ entry/ beau-willimon-kevin-spacey-sexualharassment n 59f74ad9e4b03cd20b833379?ncid=edlinkushpmg00000313

Skorobogatova, T.I. (2013). Frazeologija i istoričeskaja pamjat': interiorizacija novogo znanija v lingvistike (na materiale francuzskogo jazyka) [Phraseology and historical memory: interiorization of new knowledge in linguistics (evidence from French)]. Doctoral thesis. South Federal University.

Skoromyslova, N.V. (2003). Frazeosemantičeskoe pole psikhičeskih processov pamjati [Phraseosemantic field of mnemonic processes]. Doctoral thesis. Moscow State Region University.

Slobin, D. I. (2004). The many ways to search for a frog: Linguistic typology and the expression of motion events. In Strömqvist \& Verhoeven (Eds.) Relating events in narrative: Vol. 2. Typological and contextual perspectives (pp. 219-257): Lawrence Erlbaum Associates.

Smorti, A., Peterson, C., \& Tani, F. (2016). The Language of Memory: Narrating Memories of Parents and Friends. The Open Psychology Journal, 9(1), 95-110. https:// doi.org/ 10.2174/1874350101609010095

* Sunga, L.S. (2016, January 15). My journey back to Rwanda: confronting the ghosts of the genocide 21 years later. The Guardian. Retrieved from: 
https:// www.theguardian.com/global-development-professionalsnetwork/ 2016/jan/ 15/ my-journey-back-to-rwanda-confronting-the-ghosts-ofthe-genocide-21-years-later

* Sweet, J. (2017, August 17). Why all races need to speak against racism. The Huffpost. Retrieved from: https:/ / www.huffpost.com/ entry/ why-all-races-need-to-speakagainst-racism b 5995c2ebe4b00dd984e37d0b

Talmy, L. (1985). Lexicalization patterns: semantic structure in lexical forms. In Shopen T. (ed.) Language typology and semantic description. Vol. 3: Grammatical categories and the lexicon (pp. 36-149). Cambridge University Press.

* Tsipursky, G. (2018, January 19). Why Trump's silly fake news awards are not funny. The Newsweek. Retrieved from: https:// www.newsweek.com/ why-trumps-sillyfake-news-awards-are-not-funny-785517

Tivyaeva, I. (2014). Representation of retrospective memory and communicative context. Jezikoslovlje, 15(2-3), 283-306.

Tivyaeva, I. (2017). Sharing autobiographical memories in English computer-mediated discourse: a linguist's perspective. Brno Studies in English, 43(2), 57-78. https:// doi.org/ 10.5817/ BSE2017-2-3

Uehara, I. (2015). Developmental Changes in Memory-Related Linguistic Skills and Their Relationship to Episodic Recall in Children. PLoS One, 10(9), e0137220. https:// doi.org/ 10.1371/ journal.pone.0137220

Wertsch, J.V. (2008). The Narrative Organization of Collective Memory. Ethos, 36(1), 120-135. https:// doi.org/ 10.1111/j.1548-1352.2008.00007.x

* What was the name of the tortoise in the seventies kids programme "Pipkins"? The Guardian. Retrieved from: https:// www.theguardian.com/ notesandqueries/ query/ 0,5753,-14216,00.html

Wierzbicka, A. (2001). Sopostavlenie kul'tur cherez posredstvo leksiski i pragmatiki [Comparing cultures via lexis and pragmatics]. Yazyki slavjanskoj kul'tury.

Wierzbicka, A. (2007). Is "remember" a universal human concept? "Memory" and culture. In M. Amberber (Ed.), The Language of Memory in a Crosslinguistic Perspective. (Human Cognitive Processing) (pp. 13-39). John Benjamins B.V. https:// doi.org/ 10.1075/ hcp.21.04wie

Zaliznjak, A.A. (2006). Pamjat' i zabvenie v russkoj jazykovoj kartine mira [Memory and forgetting in Russian linguistic world picture]. Materialy vtoroj meždunarodnoj konferencii po kognitivnoj nauke. 9-13 ijunja $2006 \mathrm{~g}, 2$ [Proceedings of the second international conference on cognitive science, June 9-13, 2006], (p. 275-276). St. Petersburg State University. 